UDC 544.31:546.81'86'23

\title{
THERMODYNAMIC PROPERTIES OF $\mathrm{Pb}_{6} \mathrm{Sb}_{6} \mathrm{Se}_{17}$
}

\author{
(c) 2017 Sh. H. Mansimova ${ }^{1}$, E. N. Orujlu ${ }^{2}$, S. G. Sultanova ${ }^{1}$, M. B. Babanly ${ }^{2}$ \\ ${ }^{1}$ Baku State University, 23 Z. Khalilov, Az-1148 Baku, Azerbaijan \\ ${ }^{2}$ Institute of Catalysis and Inorganic Chemistry, Azerbaijan National Academy of Sciences, \\ 113 H. Javid ave., Az-1143 Baku, Azerbaijan \\ e-mail:Babanlymb@gmail.com
}

Received23.10.2017

\begin{abstract}
The $\mathrm{Pb}-\mathrm{Sb}-\mathrm{Se}$ system was investigated in the $\mathrm{PbSe}-\mathrm{Pb}_{6} \mathrm{Sb}_{6} \mathrm{Se}_{17}-\mathrm{Sb}_{2} \mathrm{Se}_{3}-\mathrm{Se}$ composition area and temperature range $300-450 \mathrm{~K}$ using EMF measurements on reversible concentration cells of the type

$(-) \mathrm{PbSe}(\mathrm{s}) \mid$ liquid electrolyte, $\mathrm{Pb}^{2+} \mid(\mathrm{Pb}-\mathrm{Sb}-\mathrm{Se})(\mathrm{s})(+)$.

It was shown that this subsystem consists of two three-phase regions, limited by the $\mathrm{Pb}_{6} \mathrm{Sb}_{6} \mathrm{Se}_{17}-\mathrm{Se}$ tie-line. Partial thermodynamic functions of $\mathrm{PbSe}$ and lead in tree-phase $\mathrm{Pb}_{6} \mathrm{Sb}_{6} \mathrm{Se}_{17}-\mathrm{Sb}_{2} \mathrm{Se}_{3}-\mathrm{Se}$ region are calculated from the equations for the EMF temperature dependences. The standard Gibbs energy of formation, standard enthalpy of formation and standard entropy of the $\mathrm{Pb}_{6} \mathrm{Sb}_{6} \mathrm{Se}_{17}$ compound were calculated based these data and using the thermodynamic functions for $\mathrm{PbSe}$ and $\mathrm{Sb}_{2} \mathrm{Se}_{3}$.
\end{abstract}

Keywords: lead-antimony selenides, $\mathrm{Pb}_{6} \mathrm{Sb}_{6} \mathrm{Se}_{17}$, EMF method, thermodynamic properties.

\section{INTRODUCTION}

Chalcogenides of heavy metals and complex phases based on them are the most promising thermoelectric materials. In particular, the phases of the LAST family (lead, antimony, silver, tellurium) and the tetradimite-like compounds of $\mathrm{A}^{\mathrm{IV}} \mathrm{B}_{2}^{\mathrm{V}} \mathrm{Te}_{4}, \mathrm{~A}^{\mathrm{IV}} \mathrm{B}_{4}^{\mathrm{V}}{ }_{4} \mathrm{Te}_{7}$, $\mathrm{A}^{\mathrm{IV}} \mathrm{B}_{6}^{\mathrm{V}}{ }_{6} \mathrm{Te}_{10}$-type etc. (A ${ }^{\mathrm{IV}}-\mathrm{Ge}, \mathrm{Sn}, \mathrm{Pb} ; \mathrm{B}^{\mathrm{V}}-\mathrm{Sb}, \mathrm{Bi}$ ), due to their complex structures and lower values of the lattice component of heat conductivity in comparison with the initial binary compounds $\mathrm{A}^{\mathrm{IV}} \mathrm{Te}$ and $\mathrm{B}_{2} \mathrm{Te}_{3}$, have high thermoelectric efficiency [1-5]. In addition, recent studies have shown that many of these compounds are also three-dimensional topological insulators and can be used in spintronics and quantum computing [6-8].

In order to develop modern preparative methods and growth of single crystals of complex materials, it is necessary to investigate phase relationships and thermodynamic properties of the respective systems.

Taking this into account, we undertook a thermodynamic study of ternary compounds formed in the $\mathrm{A}^{\mathrm{IV}}-\mathrm{B}^{\mathrm{V}}-\mathrm{X}(\mathrm{X}-\mathrm{Se}, \mathrm{Te})$ systems by the electromotive force (EMF) method. The results of a complex study of solid-phase equilibria in the systems $\mathrm{PbSe}-\mathrm{Bi}_{2} \mathrm{Se}_{3}-\mathrm{Se}, \mathrm{SnTe}-\mathrm{Sb}_{2} \mathrm{Te}_{3}-\mathrm{Te}, \mathrm{SnTe}-\mathrm{Bi}_{2} \mathrm{Te}_{3}-\mathrm{Te}$, and $\mathrm{PbTe}-\mathrm{Bi}_{2} \mathrm{Te}_{3}-\mathrm{Te}$ as well as the standard thermodynamic functions of the compounds and solid solutions formed in them are presented by us [9-12].

In this paper, we continued to study similar systems and presented the results of a thermodynamic study of the compound $\mathrm{Pb}_{6} \mathrm{Sb}_{6} \mathrm{Se}_{17}$ by using the EMF method with glycerol electrolyte. This modification of the EMF method is successfully used for the thermodynamic study of binary and more complex metallic, semiconductor and other systems $[13,14]$.

Phase equilibria in the $\mathrm{Pb}-\mathrm{Sb}-\mathrm{Se}$ ternary system have been studied in a number of papers [15-17]. The phase diagram of the quasi-binary section $\mathrm{PbSe}-\mathrm{Sb}_{2} \mathrm{Se}_{3}$ is presented in [15, 16]. According to [15], the $\mathrm{PbSb}_{2} \mathrm{Se}_{4}$ compound with congruent melting at $891 \mathrm{~K}$ formed in the system. According to [16], the systemis characterized by the formation of $\mathrm{Pb}_{2} \mathrm{Sb}_{2} \mathrm{Se}_{5}$ compound with incongruent melting at $857 \mathrm{~K}$ also. A recently published paper [17] presents the projection of the liquidus surface and the isothermal section at $400 \mathrm{~K}$ of the $\mathrm{Pb}-\mathrm{Sb}-\mathrm{Se}$ system. The existence of three ternary compounds $\mathrm{PbSb}_{2} \mathrm{Se}_{4}, \mathrm{PbSb}_{5} \mathrm{Se}_{6}$ and $\mathrm{Pb}_{6} \mathrm{Sb}_{6} \mathrm{Se}_{17}$ is shown. According to the results of [17], the latter compound forms conodes with binary compounds $\mathrm{PbSe}, \mathrm{Sb}_{2} \mathrm{Se}_{3}$, and also elementary selenium, which leads to the formation on the phase diagram of three-phase regions $\mathrm{PbSe}-\mathrm{Pb}_{6} \mathrm{Sb}_{6} \mathrm{Se}_{17}-\mathrm{Se}$ and $\mathrm{Pb}_{6} \mathrm{Sb}_{6} \mathrm{Se}_{17}-\mathrm{Sb}_{2} \mathrm{Se}_{3}-\mathrm{Se}$.

The crystal structures of lead-antimony selenides were studied in [18-21].

\section{EXPERIMENTAL PART}

For the experiments, $\mathrm{PbSe}$ and $\mathrm{Sb}_{2} \mathrm{Se}_{3}$ binary compounds were first synthesized. These compounds melt congruently at 1352 and $863 \mathrm{~K}$ [22]. Therefore, they 
easily crystallize from melts of stoichiometric compositions. Synthesis was carried out by melting of elementary components of high purity in evacuated $\left(\sim 10^{-2} \mathrm{~Pa}\right)$ quartz ampoule at a temperature slightly higher $(20-30 \mathrm{~K})$ of melting points. The synthesis of $\mathrm{PbSe}$ was performed in the inclined two-zone furnace because of a high vapor pressure of elemental selenium at high temperature. The temperature of the hot zone was $1370 \mathrm{~K}$, and cold $900 \mathrm{~K}$ (lower than the boiling point of selenium (958 K) [23].

The alloys of the $\mathrm{Pb}-\mathrm{Sb}-\mathrm{Se}$ system were prepared by melting form the synthesized and identified starting compounds and elemental selenium. The phase compositions of the alloys were chosen using the solid-phase equilibrium diagram (Fig. 1), constructed based on data of [17]. From the each three-phase regions $\mathrm{PbSe}-\mathrm{Pb}_{6} \mathrm{Sb}_{6} \mathrm{Se}_{17}-\mathrm{Se}$ и $\mathrm{Pb}_{6} \mathrm{Sb}_{6} \mathrm{Se}_{17}-\mathrm{Sb}_{2} \mathrm{Se}_{3}-\mathrm{Se}$ three alloys were prepared. Taking into account the importance of the equilibrium of electrode-alloys, the cast samples were annealed at $700 \mathrm{~K}$ (about $500 \mathrm{~h}$ ) and then at $450 \mathrm{~K}(200 \mathrm{~h})$. The phase compositions of the annealed alloys were controlled by the XRD method using Bruker D8 ADVANCE diffractometer ( $\mathrm{Cu} \mathrm{K}$ radiation)

For a thermodynamic study, concentration chains of the type

(-) PbSe (s.) | liquid electrolyte, $\mathrm{Pb}^{2+} \mid \mathrm{Pb}-\mathrm{Sb}$-Se (s) (+) (1) were assembled, because concentration chains relative to the lead electrode turned out to be irreversible - the EMF values continuously decreased during the experiments. Apparently, this is due to the chemical interaction between the electrodes through the electrolyte, leading to a change in their composition.

Electrodes of chains of the type (1) were prepared by pressing $\mathrm{PbSe}$ (left electrode) and annealed alloys from the above-mentioned phase regions (right electrodes) in the form of tablets with a diameter of $\sim 0.8$ $1 \mathrm{~cm}$ and a thickness of $0.4-0.6 \mathrm{~cm}$.

The electrolyte was a glycerol solution of $\mathrm{KCl}$ with addition $\mathrm{PbCl}_{2}$. Because the presence of either moisture or oxygen in the electrolyte was inadmissible, an- alytically pure glycerol was thoroughly dewatered and degassed by evacuation at $\sim 400 \mathrm{~K}$, anhydrous chemically pure $\mathrm{KCl}$ and $\mathrm{PbCl}_{2}$ were used.

The assembly of an electrochemical cell and measurements are described in detail $[13,14]$. EMF measurements were done in the temperature range of 300$450 \mathrm{~K}$ with the accuracy of $\pm 0.1 \mathrm{mV}$ using the highresistance universal B7-34A digital voltmeter.

\section{RESULTS}

The results of EMF measurements were in accordance with Fig.1 [17], according to which three-phase regions $\mathrm{PbSe}-\mathrm{Pb}_{6} \mathrm{Sb}_{6} \mathrm{Se}_{17}-\mathrm{Se}$ and $\mathrm{Pb}_{6} \mathrm{Sb}_{6} \mathrm{Se}_{17}-\mathrm{Sb}_{2} \mathrm{Se}_{3}-\mathrm{Se}$ exist in the $\mathrm{Pb}-\mathrm{Sb}$-Se system in the subsolidus. We obtained two series of EMF values that corresponded to these regions.

In the three-phase region of $\mathrm{PbSe}-\mathrm{Pb}_{6} \mathrm{Sb}_{6} \mathrm{Se}_{17}-\mathrm{Se}$, the EMF values were close to zero $(2-5 \mathrm{mV})$. This is due to the presence of the PbSe phase in both electrodes. For thermodynamic calculations, the results of EMF measurements in the three-phase region $\mathrm{Pb}_{6} \mathrm{Sb}_{6} \mathrm{Se}_{17}-\mathrm{Se}$ were used. As can be seen from Fig. 2, the EMF dependences on temperature in this phase region are linear. Accordingly, the linear least-square

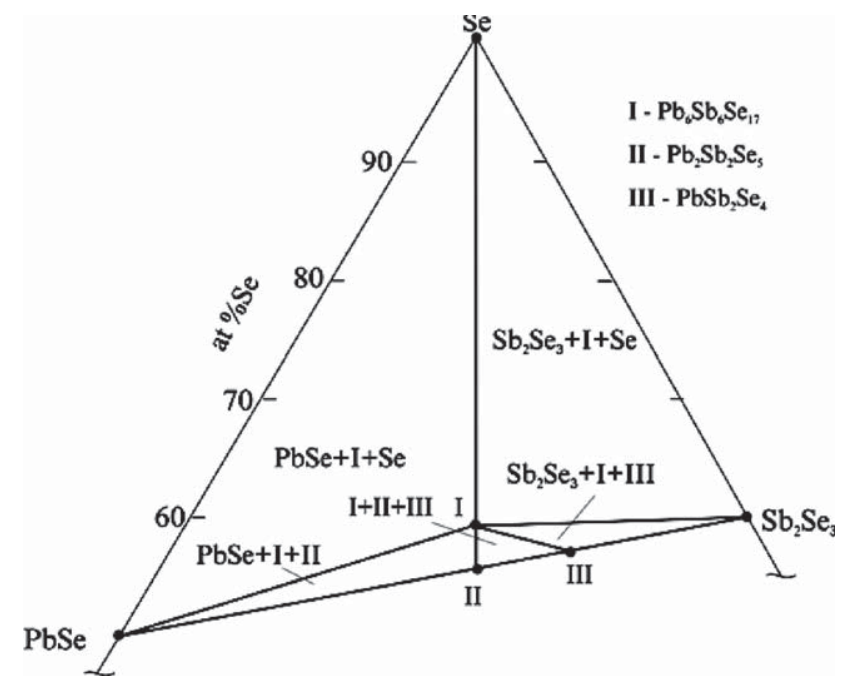

Fig. 1. Solid-phase equilibria diagram of the $\mathrm{PbSe}_{-} \mathrm{Sb}_{2} \mathrm{Se}_{3}-\mathrm{Se}$ system

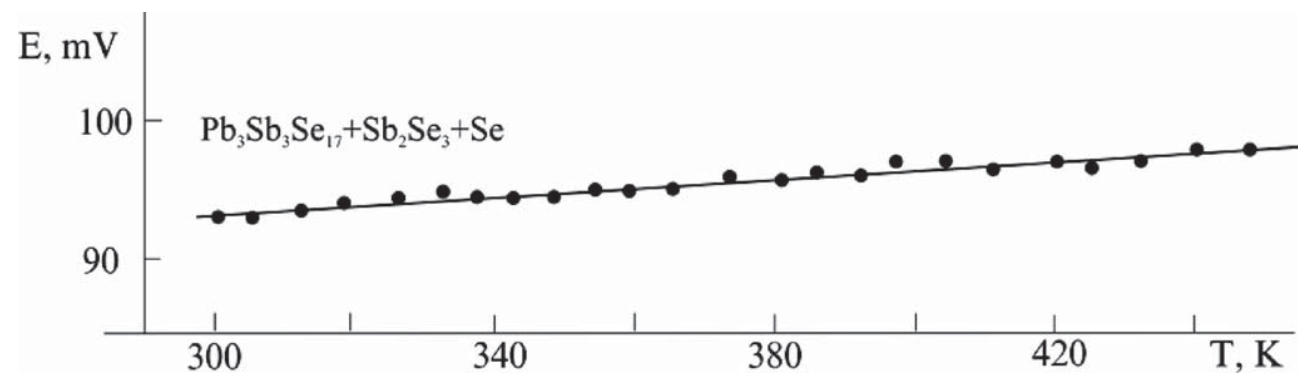

Fig. 2. EMF dependences on temperature for $\mathrm{Pb}_{6} \mathrm{Sb}_{6} \mathrm{Se}_{17}-\mathrm{Sb}_{2} \mathrm{Se}_{3}-\mathrm{Se}$ three-phase alloys 
treatment of the data was performed and the results were expressed according to the literature recommendations [13] as:

$$
E=a+b T \pm t\left[\frac{S_{E}^{2}}{n}+\frac{S_{E}^{2}(T-\bar{T})^{2}}{\sum\left(T_{i}-\bar{T}\right)^{2}}\right]^{\frac{1}{2}},
$$

where $n$ is the number of pairs of $E$ and $T$ values; $S_{\mathrm{E}}$ is the error variance of the EMF readings; $T$ is the mean absolute temperature; $t$ is the Student's test. At the confidence level of $95 \%$ and $n \geq 20$, the Student's test is $t \leq 2$. The experimental data of $T_{\mathrm{i}}$ and $E_{\mathrm{i}}$ and steps of calculation are presented in Table 1 .

From received equation

$$
\begin{gathered}
E, \mathrm{mV}=83.60+0.032 T \pm \\
\pm 2\left[\frac{0.48}{24}+1.1 \cdot 10^{-5}(T-374.3)^{2}\right]^{1 / 2}
\end{gathered}
$$

by using well known thermodynamic expressions, the partial molar functions of PbSe "component" in the alloys at $298 \mathrm{~K}$ were calculated

$$
\begin{aligned}
& \overline{\Delta G}_{\mathrm{PbSe}}=-17.95 \pm 0.11 \mathrm{KJ} \cdot \mathrm{mol}^{-1}, \\
& \overline{\Delta H}_{\mathrm{PbSe}}=-16.13 \pm 0.48 \mathrm{KJ} \cdot \mathrm{mol}^{-1}, \\
& \overline{\Delta S}_{\mathrm{PbSe}}=6.10 \pm 1.28 \mathrm{~J} \cdot \mathrm{mol}^{-1} \cdot \mathrm{K}^{-1} .
\end{aligned}
$$

These functions are the difference of the partial molar values of lead in $\mathrm{PbSe}$ and $\mathrm{Pb}_{6} \mathrm{Sb}_{6} \mathrm{Se}_{17}$ :

$$
\overline{\Delta Z}_{\mathrm{PbSe}}=\overline{\Delta Z}_{\mathrm{Pb}}-\overline{\Delta Z}_{\mathrm{Pb}}^{\prime} \text {, }
$$

where $\overline{\Delta Z}_{\mathrm{Pb}}^{\prime}$ and $\overline{\Delta Z}_{\mathrm{Pb}}$ are the partial thermodynamic functions of lead in $\mathrm{PbSe}$ and $\mathrm{Pb}_{6} \mathrm{Sb}_{6} \mathrm{Se}_{17}$, respectively.

On the other hand, because the PbSe is the only compound in the $\mathrm{Pb}-\mathrm{Se}$ system [22], the following relation is valid for it [14]

$$
\overline{\Delta Z}_{\mathrm{Pb}}^{\prime}=\Delta_{f} Z^{0}(\mathrm{PbSe}) \text {, }
$$

By combining relations (3) and (4) we obtain

$$
\overline{\Delta Z}_{\mathrm{Pb}}=\overline{\Delta Z}_{\mathrm{PbSe}}+\Delta_{f} Z^{0}(\mathrm{PbSe}) \text {. }
$$

According to $[13,14]$, and Fig.1, the functions $\overline{\Delta Z}_{\mathrm{Pb}}$ in the $\mathrm{PbSe}-\mathrm{Pb}_{6} \mathrm{Sb}_{6} \mathrm{Se}_{17}-\mathrm{Se}$ three-phase region are the thermodynamic functions of the following potential-forming reaction:

Table 1.The experimental data of $T_{\mathrm{i}}$ and $E_{\mathrm{i}}$ and steps of calculation for the phase region $\mathrm{Pb}_{6} \mathrm{Sb}_{6} \mathrm{Se}_{17}-\mathrm{Se}$ of the $\mathrm{Pb}$-Sb-Se system

\begin{tabular}{|c|c|c|c|c|c|c|c|}
\hline$T i, \mathrm{~K}$ & $E_{i}, \mathrm{mV}$ & $T_{i}-\bar{T}$ & $E_{i}\left(T_{i}-\bar{T}\right)$ & $\left(T_{i}-\bar{T}\right)^{2}$ & $\tilde{E}$ & $E_{i}-\tilde{E}$ & $\left(E_{i}-\tilde{E}\right)^{2}$ \\
\hline 302.6 & 93.2 & -71.67 & -6679.33 & 5136.11 & 93.17 & 0.03 & 0.00 \\
\hline 310.1 & 93.5 & -64.17 & -5999.58 & 4117.36 & 93.41 & 0.09 & 0.01 \\
\hline 315.5 & 93.8 & -58.77 & -5512.31 & 3453.52 & 93.58 & 0.22 & 0.05 \\
\hline 320.2 & 93.1 & -54.07 & -5033.61 & 2923.20 & 93.73 & -0.63 & 0.39 \\
\hline 328.7 & 94.8 & -45.57 & -4319.72 & 2076.32 & 94.00 & 0.80 & 0.65 \\
\hline 336.8 & 94.3 & -37.47 & -3533.11 & 1403.75 & 94.25 & 0.05 & 0.00 \\
\hline 341.5 & 93.1 & -32.77 & -3050.58 & 1073.65 & 94.40 & -1.30 & 1.69 \\
\hline 347.4 & 94 & -26.87 & -2525.47 & 721.82 & 94.59 & -0.59 & 0.35 \\
\hline 353.3 & 95.9 & -20.97 & -2010.70 & 439.60 & 94.77 & 1.13 & 1.27 \\
\hline 358 & 95.1 & -16.27 & -1546.96 & 264.60 & 94.92 & 0.18 & 0.03 \\
\hline 367.3 & 95.5 & -6.97 & -665.32 & 48.53 & 95.22 & 0.28 & 0.08 \\
\hline 372.6 & 95.8 & -1.67 & -159.67 & 2.78 & 95.38 & 0.42 & 0.17 \\
\hline 377.5 & 95.7 & 3.23 & 309.43 & 10.45 & 95.54 & 0.16 & 0.03 \\
\hline 381.7 & 95.3 & 7.43 & 708.40 & 55.25 & 95.67 & -0.37 & 0.14 \\
\hline 387.1 & 95 & 12.83 & 1219.17 & 164.69 & 95.84 & -0.84 & 0.71 \\
\hline 395.8 & 97.5 & 21.53 & 2099.50 & 463.68 & 96.12 & 1.38 & 1.91 \\
\hline 401.3 & 96 & 27.03 & 2595.20 & 730.80 & 96.29 & -0.29 & 0.09 \\
\hline 406.6 & 96.8 & 32.33 & 3129.87 & 1045.44 & 96.46 & 0.34 & 0.12 \\
\hline 410.4 & 95.9 & 36.13 & 3465.19 & 1305.62 & 96.58 & -0.68 & 0.46 \\
\hline 419.7 & 95.2 & 45.43 & 4325.25 & 2064.19 & 96.87 & -1.67 & 2.80 \\
\hline 425.2 & 97.7 & 50.93 & 4976.19 & 2594.20 & 97.05 & 0.65 & 0.42 \\
\hline 434.5 & 97.5 & 60.23 & 5872.75 & 3628.05 & 97.34 & 0.16 & 0.02 \\
\hline 440.4 & 97.8 & 66.13 & 6467.84 & 4373.62 & 97.53 & 0.27 & 0.07 \\
\hline 448.2 & 98 & 73.93 & 7245.47 & 5466.14 & 97.78 & 0.22 & 0.05 \\
\hline $\bar{T}=374.26$ & $\bar{E}=95.44$ & & $\sum E\left(T_{i}-\bar{T}\right)=1377.89$ & $\sum\left(T_{i}-\bar{T}\right)^{2}=43563.41$ & & & $\sum\left(E_{i}-\tilde{E}\right)^{2}=11.51$ \\
\hline
\end{tabular}




$$
\mathrm{Pb}+0.5 \mathrm{Sb}_{2} \mathrm{Se}_{3}+\frac{4}{3} \mathrm{Se}=\frac{1}{6} \mathrm{~Pb}_{6} \mathrm{Sb}_{6} \mathrm{Se}_{17} .
$$

According to this relation, the standard thermodynamic functions of formation of the $\mathrm{Pb}_{6} \mathrm{Sb}_{6} \mathrm{Se}_{17}$ compound may be calculated as

$$
\Delta_{f} Z^{0}\left(\mathrm{~Pb}_{6} \mathrm{Sb}_{6} \mathrm{Se}_{17}\right)=6 \overline{\Delta Z}_{\mathrm{Pb}}+3 \Delta_{f} Z^{0}\left(\mathrm{Sb}_{2} \mathrm{Se}_{3}\right)
$$

$(Z \equiv G, H)$ while standard entropy

$$
\begin{gathered}
S^{0}\left(\mathrm{~Pb}_{6} \mathrm{Sb}_{6} \mathrm{Se}_{17}\right)= \\
=6 \overline{\Delta S}_{\mathrm{Pb}}+6 S^{0}(\mathrm{~Pb})+3 S^{0}\left(\mathrm{Sb}_{2} \mathrm{Se}_{3}\right)+2 S^{0}(\mathrm{Se}) .
\end{gathered}
$$

In calculations we used literature data on the relevant thermodynamic data on $\mathrm{PbSe}$ and $\mathrm{Sb}_{2} \mathrm{Se}_{3}$ (Table 2) and the standard entropies of lead $\left(64.81 \pm 0.21 \mathrm{~J} \cdot \mathrm{K}^{-1} \cdot \mathrm{mol}^{-1}\right)$ and selenium $\left(42.13 \pm 0.21 \mathrm{~J} \cdot \mathrm{K}^{-1} \cdot \mathrm{mol}^{-1}\right)$ presented in Ref. [24]. The standard integral thermodynamic functions of $\mathrm{PbSe}$ and $\mathrm{Sb}_{2} \mathrm{Se}_{3}$ used in our calculations are self consistent and quite reliable. The standard heats of formation and standard entropies recommended in several handbooks and review articles [24-27] for these compounds are essentially identical, and their standard Gibbs energies of formation calculated by us from their enthalpy and entropy of formation agree very well with data obtained from EMF measurements [26-28].

As a result of the calculations by relation (5), we obtained the following partial molar functions of the lead in $\mathrm{Pb}_{6} \mathrm{Sb}_{6} \mathrm{Se}_{17}$

$$
\begin{aligned}
& \overline{\Delta G}_{\mathrm{Pb}}=-114.45 \pm 3.11 \mathrm{~kJ} \cdot \mathrm{mol}^{-1}, \\
& \overline{\Delta H}_{\mathrm{Pb}}=-116.13 \pm 2.58 \mathrm{~kJ} \cdot \mathrm{mol}^{-1}, \\
& \overline{\Delta S}_{\mathrm{Pb}}=-5.63 \pm 3.38 \mathrm{~J} \cdot \mathrm{K}^{-1} \cdot \mathrm{mol}^{-1} .
\end{aligned}
$$

The standard integral thermodynamic functions of the $\mathrm{Pb}_{6} \mathrm{Sb}_{6} \mathrm{Se}_{17}$ calculated using relations (6) and (7) and thermodynamic data of the binary compounds (Table 2). The estimated standard deviations were calculated by accumulating the errors.

\section{CONCLUSION}

By using the EMF method the self-consistent data on the standard integral thermodynamic functions of the $\mathrm{Pb}_{6} \mathrm{Sb}_{6} \mathrm{Se}_{17}$, which is interest as a thermoelectric material are obtained.

\section{ACKNOWLEDGMENT}

The work has been carried out within the framework of the international joint research laboratory "Advanced Materials for Spintronics and Quantum Computing" (AMSQC) established between Institute of Catalysis and Inorganic Chemistry of ANAS (Azerbaijan) and Donostia International Physics Center (Basque Country, Spain).

\section{REFERENCES}

1. Shevelkov A.V.Russ. Chem. Rev.,2008, vol.77, pp. 1-19. (in Russian)

2. Kuei Fang Hsu, Sim Loo, Fu Guo, Wei Chen, Jeffrey S. Dyck, Ctirad Uher, Tim Hogan, E. K. Polychroniadis, Mercouri G. Kanatzidis. Science, 2004, vol. 303, pp. 818821.DOI: 10.1126/science. 1092963

3. Poudeu P. F. P., Angelo J. D., Kong H., Downey A., Short J. L., Pcionek R., Hogan T. P., Uher C., Kanatzidis M. G. J. Am. Chem. Soc., 2006, vol. 128, pp. 1434714355. DOI: $10.1021 / \mathrm{ja} 0647811$

4. Chen Y., Zhu T. J., Yang S. H., Yu C., Zhao X. B. J. Phys. D: Appl. Phys. 43 (2010), 035405. Available at: http://iopscience.iop.org/article/10.1088/0022-3727/43/ $3 / 035405 /$ pdf

5. Zemskov V. S., Shelimova L. E., Konstantinov P. P., Avilov E. S., Kretova M. A., Nikhezina I. Yu. Inorg. Mater.: Appl. Res., 2012, vol. 3, pp. 61-69. DOI: 10.1134/ S2075113314010158

6. Niesner D., Otto S., Hermann V., Fauster Th. et al. Phys. Rev. B, 2014, vol. 89, pp. 081404-081404-5. DOI: https://doi.org/10.1103/PhysRevB.89.081404

7. Papagno M., Eremeev S., Fujii J., Aliev Z. S. et al. ACS Nano, 2016, vol. 10, pp. 3518-3524. DOI: 10.1021/ acsnano. 5 b07750

8. Okuda T., Maegawa T., Ye M., Shirai K. et al. Phys. Rev. Lett., 2013, vol. 111, pp. 205803-5. DOI: https://doi. org/10.1103/PhysRevLett.111.206803

9. Guseinov F. N., Babanly K. N., Aliev I. I. and Babanly M. B. Russ. J. Inorg. Chem., 2012, vol. 57, no. 1, pp. 101-103. DOI: 10.1134/S003602361201010X

10. Guseinov F. N., Seidzade A. E., Yusibov Yu. A. and Babanly M. B. Inorg. Mater., 2017, vol. 53, no.4, pp. 354357. DOI: $10.1134 / \mathrm{S} 0020168517040057$

11. Babanly M. B., Guseinov F. N., Dashdiyeva G. B., Yusibov Y. A. Inorg. Mater., 2011, vol. 47, no. 3, pp. 284288. DOI: $10.1134 / \mathrm{S} 0020168511030022$

Table 2. Standard integral thermodynamic functions of $\mathrm{PbSe}, \mathrm{Sb}_{2} \mathrm{Se}_{3}$, and $\mathrm{Pb}_{6} \mathrm{Sb}_{6} \mathrm{Se}_{17}$

\begin{tabular}{|c|c|c|c|}
\hline \multirow{2}{*}{ Compound } & $-\Delta_{f} G^{0}(298 \mathrm{~K})$ & \multicolumn{1}{|c|}{$-\Delta_{f} H^{0}(298 \mathrm{~K})$} & \multirow{2}{*}{$\mathrm{k} \cdot\left(298 \mathrm{~K} \cdot \mathrm{mol}^{-1}\right.$} \\
\cline { 2 - 3 } & \multicolumn{2}{|c|}{$\mathrm{J} \cdot \mathrm{K}^{-1} \cdot \mathrm{mol}^{-1}$} \\
\hline $\mathrm{PbSe}$ & $96.5 \pm 3.0$ & $100.0 \pm 2.1[24,25]$ & $102.5 \pm 2.1[24,25]$ \\
\hline $\mathrm{Sb}_{2} \mathrm{Se}_{3}$ & $125.9 \pm 3.0$ & $127.6 \pm 1.3[25,26]$ & $212.1 \pm 3.3[25,26]$ \\
\hline $\mathrm{Pb}_{6} \mathrm{Sb}_{6} \mathrm{Se}_{17}$ & $1064 \pm 28$ & $1080 \pm 20$ & $1387 \pm 35$ \\
\hline
\end{tabular}


12. Babanly M. B., Shevelkov A. V., Guseinov F. N., Babanly D. M. Inorg. Mater., 2011, vol. 47, no.7, pp. 712716. DOI: $10.1134 / \mathrm{S} 002016851107003 \mathrm{X}$

13. Morachevskii A. G., Voronin G. F., Geiderikh V. A. and Kutsenok I. B. Electrochemical Characterization Techniques in Thermodynamic Studies of Metallic Systems. Moscow, Akademkniga Publ., 2003. (in Russian)

14. Babanly M. B. and Yusibov Yu. A. Electrochemical Characterization Techniques in Thermodynamic Studies of Inorganic Systems. Baku, ELM Publ., 2011.

15. Shelimova L. E., Tomashik V. N. and Grytsiv V. I. Phase Diagrams in Semiconductor Materials Research: Systems Based on Chalcogenides of Si, Ge, Sn, and Pb. Moscow, Nauka Publ., 1991. (in Russian)

16. Olekseyuk I. D., Ostapyuk T. A., Viskynets L. M., Zmiy O. F. Scientific Journal Volyn National University, 2010, no.16, pp. 38-42.

17. Chang J., Chen S. J. Alloys Compd., 2016, vol. 666, pp. 159-169. https://doi.org/10.1016/j.jallcom.2016. 01.051

18. Skovrov A., Bosvel F. W., Corbet J. M., Taylor N. J. J. SolidState Chem., 1994, vol. 112, pp. 251-254. https://doi. org/10.1006/jssc. 1994.1300

19. Skowron A., Brown I. D. Acta Cryst. Section C, 1990, vol. 46, no. 12,pp. 2287-2291. DOI: 10.1107/ S010827019000405X

20. Derakhshan S., Assound A., Taylor N.J., Kleinke H. Intermetallics, 2006, vol. 14, no. 2, pp. 198-207. https://doi. org/10.1016/j.intermet.2005.05.008
21. Emirdag-Eanes M, Kolis J. W. Z. Anorg. Allg. Chem., 2002, vol. 628, no. 1, pp. 10-11. DOI: 10.1002/15213749(200201)628:1<10::AID-ZAAC10>3.0.CO;2-1

22. Binary Alloys Phase Diagrams. Ed. by T. B. Massalski, second edition. ASM International, Materials park, Ohio, 1990, 3589 p.

23. Emsley J. The Elements.Third ed., Clarendon Press, 1998, 292 p.

24. Kubaschewski O., Alcock C. B., Spenser P. J. Materials Thermochemistry. 6-th edition, Pergamon Press, England, 1993, 363 p.

25. Data base of thermal constants of substances. Digital version, in: V. S. Iorish, V. S. Yungman, (Eds.), 2006. Available at: http://www.chem.msu.ru/cgi-bin/tkv.pl

26. Gerasimov Ya. I., Krestovnikov A. N. and Gorbov S. I., Chemical Thermodynamics in Nonferrous Metallurgy: A Handbook. Moscow, Metallurgiya Publ., 1974, vol. 6, 312 p. (in Russian)

27. Melekh B. T., Semenkovich S. A. and Andreev A. A. Thermodynamic Properties of Intermetallic Phases. Kiev, Inst. Problem Materialovedeniya Publ., 1982, pp. 73-87. (in Russian)

28. Babanly M. B., Yusibov Yu. A. and Abishev V. T. EMF Measurements in Thermodynamic Studies of Complex Semiconductors. Baku, Bak. State. Univ. Publ., 1992, $317 \mathrm{p}$.

\section{УДК 544.31:546.81'86'23}

\section{ТЕРМОДИНАМИЧЕСКИЕ СВОЙСТВА $\mathrm{Pb}_{6} \mathrm{Sb}_{6} \mathrm{Se}_{17}$}

\section{(c) 2017 Ш. Г. Мансимова ${ }^{1}$, Э. Н. Оруджлу르, С. Г. Султанова ${ }^{1}$, М. Б. Бабанлы ${ }^{2}$}

${ }^{1}$ Бакинский государственный университет, ул. Академика Захида Халилова, 23, AZ 1148 Баку, Азербайджан

${ }^{2}$ Институт катализа и неорганической химии НАНА, пр. Г. Джавида, 113, AZ 1143 Баку, Азербайджан e-mail:Babanlymb@gmail.com

Поступила в редакцию 23.10.2017

Аннотация. Измерением ЭДС обратимых концентрационных цепей типа:

(-) $\mathrm{PbSe}$ (тв.) $\mid$ жидкий электролит, $\mathrm{Pb}^{2+} \mid(\mathrm{Pb}-\mathrm{Sb}-\mathrm{Se})($ тв.)(+)

в интервале температур 300-450 K исследована система $\mathrm{Pb}-\mathrm{Sb}-\mathrm{Se}$ в области составов $\mathrm{PbSe}-$ $\mathrm{Pb}_{6} \mathrm{Sb}_{6} \mathrm{Se}_{17}-\mathrm{Sb}_{2} \mathrm{Se}_{3}-\mathrm{Se}$. Показано, что эта подсистема состоит из двух трехфазных областей, разделенных коннодой $\mathrm{Pb}_{6} \mathrm{Sb}_{6} \mathrm{Se}_{17}-\mathrm{Se}$. Из данных измерений ЭДС для трехфазной области $\mathrm{Pb}_{6} \mathrm{Sb}_{6} \mathrm{Se}_{17}-\mathrm{Sb}_{2} \mathrm{Se}_{3}-\mathrm{Se}$ получено линейное уравнение типа $E=a+b T \pm t S_{E}(T)$, с использованием которого вычислены парциальные термодинамические функции PbSe в сплавах. Комбинированием этих данных с термодинамическими функциями образования $\mathrm{PbSe}$ рассчитаны парциальные термодинамические функции свинца. На основании полученных данных и диаграммы твердофазных равновесий подсистемы $\mathrm{PbSe}-\mathrm{Pb}_{6} \mathrm{Sb}_{6} \mathrm{Se}_{17}-\mathrm{Sb}_{2} \mathrm{Se}_{3}-\mathrm{Sec}$ использованием соответствующих термодинамических функций $\mathrm{Sb}_{2} \mathrm{Se}_{3}$ рассчитаны стандартные свободная энергия Гиббса образования и энтальпия образования, а также стандартная энтропия соединения $\mathrm{Pb}_{6} \mathrm{Sb}_{6} \mathrm{Se}_{17}$.

Ключевые слова: система $\mathrm{Pb}-\mathrm{Sb}-\mathrm{Se}, \mathrm{Pb}_{6} \mathrm{Sb}_{6} \mathrm{Se}_{17}$, метод ЭДС, термодинамические свойства. 
Работа выполнена в рамках международной совместной исследовательской лаборатории «Передовые материаль для квантового компьютинга и спинтроники» (AMSQC), созданной между Институтом катализа и неорганической химии НАНА (Азербайджан) и Международным Физическим Центром Доностии (Испания).
Мансимова Шабнам Г. - аспирант Бакинского государственного университета; тел.: (+994) 502296446

Оруджлу Эльнур Н.-магистрант Института катализа и неорганической химии Национальной Академии наук Азербайджана

Султанова Самина Г. - аспирант Бакинского государственного университета; тел.: (+994) 556002213

Бабанль Магомед Баба огль - д. х. н, профессор, зам. директора Института катализа и неорганической химии Национальной Академии наук Азербайджана; тел.: (+995) 518378621, e-mail: babanlymb@gmail.com
Mansimova Shabnam Hamlet - PhD student of Baku State University;ph.: (+994) 502296446

Orujlu Elnur Najaf - magistrate of Institute of Catalysis and Inorganic Chemistry Azerbaijan National Academy of Sciences

Sultanova Samina Geys-PhD student of Baku State University; ph.: (+994) 556002213

Babanly Mahammad Baba - Dr. Sci. (Chem.), Deputy Director of Institute of Catalysis and Inorganic Chemistry Azerbaijan National Academy of Sciences; ph.: (+995) 518378621, e-mail: babanlymb@gmail.com 